\title{
PENINGKATAN AKTIVITAS BELAJAR PKN MELALUI PEMBELAJARAN KOOPERATIF TIPENUMBERED HEADS TOGETHER (NHT) DI KELASVI SD NEGERI 088 PANYABUNGAN
}

\author{
Nirwana Elita \\ Guru SD Negeri 088 Penyabungan \\ Surel: nirwanaelita@yahoo.co.id
}

\begin{abstract}
Abstrak
Penelitian ini bertujuanUntuk mengetahui aktivitas belajar siswa siswa kelas VI SD Negeri 088 Panyabungan. Pada Siklus I rata-rata nilai tes 71 dengan ketuntasan pembelajaran sebesar 54,34\% dan pada Siklus II rata-rata nilai tes 86 dengan ketuntasan pembelajaran naik menjadi 91,30. Data aktivitas siswa menurut pengamat pada Siklus I antara lain menulis/membaca (37\%), bekerja (19\%), bertanya sesama teman (15\%), bertanya kepada guru (18\%), dan yang tidak relevan dengan KBM (11\%). Data aktivitas siswa menurut pengamatan pada Siklus II antara lain menulis/membaca (27\%), bekerja (32\%), bertanya sesama teman $(23 \%)$, bertanya kepada guru $(15 \%)$, dan yang tidak relevan dengan KBM (4\%). Sehingga terjadi perbaikan aktivitas belajar siswa dalam dua siklus.
\end{abstract}

Kata Kunci : Aktivitas, Kooperatif, Numbered heads together

\section{PENDAHULUAN}

Sukses dan keberhasilan dalam belajar mengajar peran guru sangat menunjang dalam upaya meningkatkan aktivitas belajar anak didik yang bermuara pada hasil belajar nantinya. Untuk memperbaiki strategi belajar, guru perlu menentukan dan membuat perencanaan pengajaran secara seksama. Hal tersebut menuntut adanya perubahan-perubahan dalam pengorganisasian kelas. Strategi belajar mengajar, penggunaan metode pengajaran maupun perilaku dan sikap guru dalam mengelola proses belajar mengajar sangat dibutuhkan dalam pembelajaran. Hal ini dilakukan untuk mempermudah siswa dalam menerapkan pengetahuannya di masyarakat dan lingkungannya.

Peranan guru terlihat dari proses belajar mengajar yang dilakukakan di dalam kelas. Kegiatan belajar mengajar yang berjalan baik akan menunjang hasil belajar yang lebih baik. Dengan pemanfaatan waktu seefisien mungkin dan mencapai tujuan pembelajaran. Keadaan yang kondusif, tenang dan nyaman adalah hal pertama yang mesti diciptakan guru didalam kelas sebelum memasuki kegiatan inti dari pembelajaran. Siswa/i SD lebih 
banyak bermainnya dari pada belajar menempatkan posisi dirinya di dalam kelas. Ketika guru belum hadir didalam kelas kerap kali dijumpai suasana kelas yang siswanya ada yang berkejarkejaran, ribut. Hal ini akan membuat siswa - siswi lelah dan kehilangan konsentrasinya untuk menerima pelajaran. Untuk itu diperlukan keterampilan khusus guru untuk menenangkan dan memotivasi siswa untuk belajar dengan baik.

Siswa SD merupakan anakanak didik yang menerima materimateri dasar yang akan menjadi dasar bagi anak didik untuk melanjutkan pelajaran kejenjang yang lebih tinggi. Dasar yang kuat akan memudahkan anak didik menerima pelajaran yang lebih luas. Akan menjadi sebaliknya jika hasil belajar yang rendah yang didapatkan siswa akan membuat siswa kesulitan dalam menghadapi pelajaran yang akan datang. Penyampain materi dari guru dengan divariasikan dengan menggunakan media akan membantu penyampaian materi, ilustrasi. Menarik perhatian siswa untuk mengikuti pelajaran lebih serius. Hal-hal yang sama setiap kegiatan belajar mengajar yang dijumpai siswa akan lebih sedikit dan menghindari kejenuhan siswa dalam belajar.

Pelajaran PKn dipenuhi oleh materi wacana. Menuntut kemampuan siswa dalam hal membaca, mengamati, mengingat dan memahami seperti yang terdapat pada materi mata pelajaran PKn tahun pembelajaran 2014/2015. Disinilah peran guru sangat menentukan untuk membimbing anak didiknya dalam belajar. Penggunaan media yang relevan, pemilihan kosa kata yang tepat untuk mempermudah penyampaian materi dan beberapa hal untuk membangkitkan suasana belajar didalam kelas. Merangsang siswa untuk aktif dalam belajar. Membantu siswa menemukan kesulitan dalam belajar, mendukung siswa untuk berani mengemukakan pendapat didepan kelas ataupun disaat pembelajaran berlangsung.

Sebagai guru, mempersiapkan diri sebelum memulai pembelajaran dengan mempertimbangkan metode ataupun model pembelajaran yang akan dipakai sangat menentukan kualitas pembelajaran dalam kelas. Mempersiapkan media pembelajaran untuk membantu guru dalam upaya penyampaian materi pelajaran. Numbered Heads Together adalah salah satu teknik dari model pembelajaran kooperatif. Teknik belajar mengajar kepala bernomor (numbered heads Together) dikembangkan oleh Spencer Kagen (Lie, 2004). Teknik ini memberikan kesempatan kepada siswa untuk saling membagikan ide - ide dan mempertimbangkan jawaban yang paling tepat.

Model kooperatif merupakan model pembelajaran 
berkelompok yang melibatkan siswa dalam kelompok belajar. Penerapan tipe Numbered Heads Together dalam proses belajar mengajar PKn akan mengatasi kesulitan belajar siswa dan mengantar siswa dalam suasana kelas yang aktif, membangkitkan semangat dan rasa ingin tahu siswa, menuntut kerja sama dalam kelompok, serta menyita waktu murid untuk menyelesaikan tugasnya sehingga tidak ada waktu bagi mereka untuk bermain dan bergurau.

Berdasarkan latar belakang, maka yang menjadi identifikasi masalah dalam peningkatan aktivitas belajar siswa melalui Model Pembelajaran Kooperatif Tipe Numbered Head Together ditetapkan:

a. Pembelajaran yang diterapkan guru belum mampu meningkatkan aktivitas siswa dalam belajar

b. Daya serap siswa memahami materi berbeda-beda pada pelajaran PKn

c. Pembelajaran masih monoton, guru dalam menyampaikan materi masih dengan cara-cara konvensional, media yang digunakan guru kurang memadai dalam menunjang proses belajar mengajar

d. Sebagaian besar siswa masih belum mencapai nilai batas KKM

Untuk menyelesaikan masalah-masalah yang dihadapi siswa, maka peneliti membatasi permasalahan sesuai dengan kemampuan peneliti antara lain;

a. Menggunakan Model Kooperatif Tipe Numbered Head Together.

b. Subjek penelitian adalah siswa kelas VI-A SD Negeri 088 Panyabungan Kabupaten Mandailing Natal tahun pembelajaran 2014/2015.

c. Materi yang diterapkan selama pengambilan data adalah sistem pemerintahan Republik Indonesia.

d. Kurikulum yang digunakan adalah KTSP.

Untuk memperjelas masalah yang akan dibahas, maka rumusan masalah ditetapkan : Apakah aktivitas belajar siswa kelas VI-A SD Negeri 088 Panyabungan Kabupaten Mandailng Natal Tahun Pembelajaran 2014/2015 meningkat setelah menerapkan Model Pembelajaran Kooperatif Tipe Numbered Head Together pada mata pelajaran PKn? Pemecahan masalah dalam penelitian ini yaitu dengan menerapkan model pembelajaran Kooperatif Tipe Numbered Head Together (NHT). Penerapan model pembelajaran ini diharapkan mampu meningkatkan aktivitas belajar yang bermuara pada perbaikan hasil belajar siswa.

Setelah menetapkan rumusan masalah di atas maka, dapat ditentukan tujuan penelitian ini adalah Untuk mengetahui aktivitas belajar siswa kelas VI-A 
SD Negeri 088 Panyabungan Tahun Pembelajaran 2014/2015 apakah meningkat setelah menerapkan Model Pembelajaran Kooperatif Tipe Numbered Head Together pada mata pelajaran PKn.

Hasil-hasil penelitian ini dapat dimanfaatkan oleh:

a. Guru-guru SD Negeri 088 Panyabungan Kabupaten Mandailing Natal dan guruguru yang lain untuk menambah wawasan dalam pengembangan profesi guru.

b. Menambah kepustakaan bagi guru-guru tentang model pembelajaran Kooperatif Tipe Numbered Head Together.

c. Khususnya bagi kepala sekolah sebagai bahan pertimbangan untuk menerapkan model pembelajaran Kooperatif Tipe Numbered Head Together di sekolah.

\section{METODOLOGI PENELITIAN}

Penelitian ini dilakukan di SD Negeri 088 Panyabungan. Waktu pelaksanaannya pada bulan September sampai dengan Desember 2014.

Pengambilan data untuk penelitian ini ditentukan di kelas VI. Subjek yang digunakan untuk pengambilan data adalah kelas VIA yang berjumlah 46 orang.Penentuan kelas VI-A sebagai subjek penelitia karena peneliti adalah guru PKn dikelas ini.
Dalam buku pedoman teknis pelaksanaan Classroom Action Research (CAR) atau Penelitian Tindakan Kelas (Depdiknas, 2001:5) disebutkan penelitian bersiklus, tiap siklus terdiri dari :
a. Perencanaan
b. Tindakan (Action)
c. Observasi
d. Refleksi

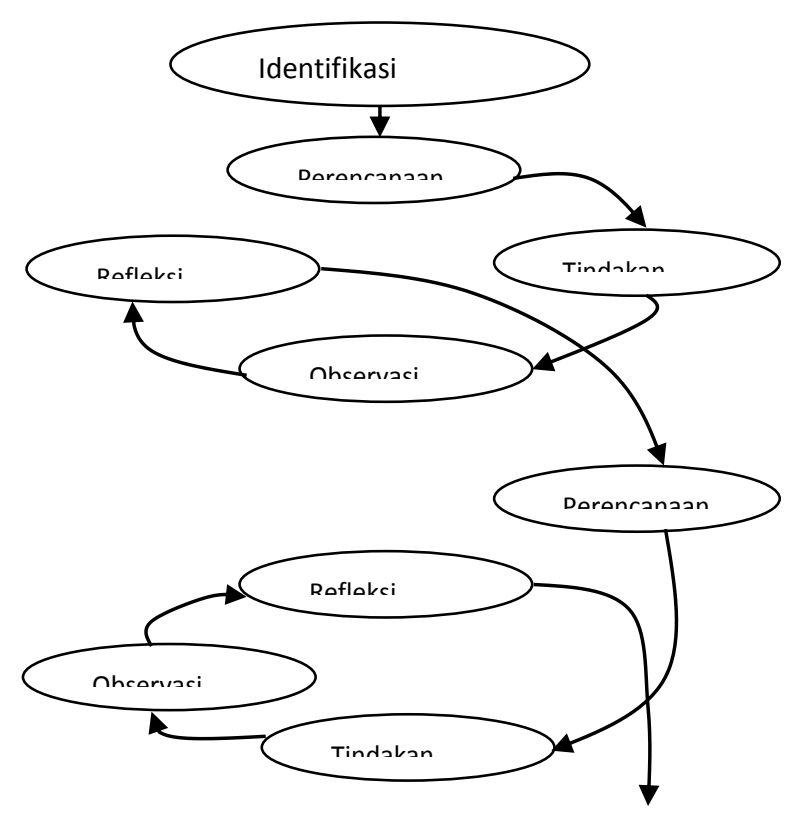

Gambar 3.1 : Spiral Tindakan Kelas (Hopkins dalam Aqib, 2006: 31)

Instrumen penelitian disusun melalui diskusi kolaborasi antara peneliti dengan guru sejawat, pembimbing, dan nara sumber dosen dari UNIMED. Perangkat Siklus I disusun dalam perencanaan Siklus I. Sementara dalam Siklus II perangkat disusun dalam perencanaan Siklus II, ini dimaksudkan agar teridentifikasi 
kelemahan pembelajaran dan tersusun rencana yang direvisi terlebih dahulu. Instrumen yang digunakan dalam penelitian ini terdiri dari:

a. Rencana Pelaksanaan Pembelajaran (RPP)

Yaitu merupakan perangkat pembelajaran yang digunakan sebagai pedoman guru dalam mengajar dan disusun untuk tiap siklus. Masing - masing RPP berisi kompetensi dasar, indikator pencapaian hasil belajar, tujuan pembelajaran khusus, dan kegiatan belajar mengajar.

b. Lembar Observasi Kegiatan Belajar Mengajar

Istrumen ini terdiri dari lembar observasi aktivitas siswa dalam pembelajaran dan lembar observasi pengelolaan model pembelajaran kooperatif tipe Numbered Head Together oleh guru.

\section{c. Tes formatif}

Tes digunakan untuk mengetahui hasil belajar siswa sebelum dan sesudah pembelajaran dengan model kooperatif tipe Numbered Head Together. Tes disusun dalam bentuk essay yang mengacu pada Kurikulum Tingkat Satuan Pendidikan (KTSP) untuk SD Negeri 088 Panyabungan. Tes yang digunakan sebanyak 9 soal.

\section{Teknik Analisis Data}

Metode analisis data pada penelitian ini digunakan metode deskriptif dengan membandingkan hasil belajar siswa sebelum tindakan dengan hasil belajar siswa setelah tindakan.

Langkah-langkah pengolahan data sebagai berikut:

a. Merekapitulasi nilai pretes sebelum tindakan dan nilai tes akhir Siklus I dan Siklus II

b. Menghitung nilai rerata atau persentase hasil belajar siswa sebelum dilakukan tindakan dengan hasil belajar setelah dilakukan tindakan pada Siklus I dan Siklus II untuk mengetahui adanya peningkatan hasil belajar.

c. Penilaian

a) Data nilai hasil belajar (kognitif) diperoleh dengan menggunakan rumus:

Nilai Siswa $=\frac{\text { Jumlah jawaban benar }}{\text { Jumlah seluruh soal }} \times 100$

b) Nilai rata-rata siswa dicari dengan rumus sebagai berikut:

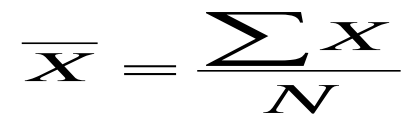

Keterangan :

$\bar{X}=$ Nilai rata-rata

$\Sigma=$ Jumlah nilai $X$

$\mathrm{N}=$ Jumlah peserta tes

c) Untuk penilaian aktivitas digunakan rumus sebagai berikut: 
\% Proporsi Aktivitas

$=\frac{\text { jumlah skor yang diperoleh }}{\text { jumlah skor ideal }} \times 100 \%$

(Majid, 2009:268)

d) Ketentuan persentase ketuntasan belajar kelas:

Ketuntasan belajar kelas $=\frac{\sum S_{b}}{K} \times 100 \%$

$\Sigma \mathrm{Sb}=$ Jumlah siswa yang mendapat nilai $\geq \mathrm{KKM}$

$\Sigma \mathrm{K}=$ Jumlah siswa dalam sampel

Sebagai tolak ukur keberhasilan penelitian tindakan kelas ini dapat dilihat dari: hasil tes, jika hasil belajar siswa mencapai KKM secara individual dan $85 \%$ secara klasikal.

\section{Indikator Keberhasilan}

Yang menjadi $\begin{aligned} & \text { indikator } \\ & \text { mengajar }\end{aligned}$
keberhasilan guru $\begin{aligned} & \text { digunakan KKM mata pelajaran } \\ & \text { PKn di sekolah dengan nilai } 70 \\ & \text { secara individual dan } 85 \% \text { secara } \\ & \text { klasikal. }\end{aligned}$

\section{HASIL PENELITIAN DAN PEMBAHASAN}

Pembelajaran menggunakan model pembelajaran kooperatif pendekatan struktural Numbered Head Together memberikan kesempatan kepada siswa untuk saling membagikan ide-ide dan mempertimbangkan jawaban yang paling tepat sehingga secara tidak langsung menuntut siswa untuk mau dan mampu mengkonstruksi pengetahuan melalui proses kelompok maupun individu melui setiap tahapan model pembelajaran di setiap Siklus. Penelitian ini dilaksanakan dalam dua siklus. Masing-masing siklus dilaksanakan dua kali pertemuan, pertemuan digunakan untuk pembahasan materi dengan alokasi waktu 2 × 35 menit.Hal ini disesuaikan dengan jadwal pelajaran PKn di kelas VIA.

Sebelum dilaksanakan Siklus I dilakukan uji awal untuk menjajaki kemampuan awal siswa dalam materi pokok Sistem Pemerintahan Republik Indonesia. Hasil pretes menunjukkan nilai dengan rata - rata 50 dengan nilai terendah 30 diperoleh 14 orang siswa dan tertinggi 75 diperoleh 3 orang siswa. Dengan ketuntasan minimal (KKM) sebesar 70 maka ketuntasan klasikal masih sebesar $13,95 \%$.

\section{Siklus I}

\section{Perencanaan}

Sebelum
tindakan siklus I, dilakukan
persiapan sebagai berikut:

a. Penetapan rancangan pembelajaran PKn beserta setrateginya yaitu peneliti menyusun rencana pelaksanaan pembelajaran (RPP) yang berisi langkah - langkah pelaksanaan model pembelajaran Numbered Heads Together (Lampiran 1).

b. Penyusunan Lembar Kerja Siswa (LKS I) yang berisi 
pertanyaan- pertanyaan yang berhubungan dengan pokok bahasan dan Indikator yang ingin dicapai. Pokok bahasan pada siklus I adalah "Pemilu dan Pilkada".

c. Penyusunan soal tes tertulis (Formatif siklus I) yang diadakan pada setiap akhir siklus untuk mengetahui hasil belajar siswa.

d. Penyusunan lembar observasi untuk mengetahui aktivitas belajar siswa

e. Guru menyiapkan daftar nama anggota kelompok. Keseluruhan jumlah siswa kelas VI dengan jumlah siswa 46 orang. Kelompok yang dibentuk adalah kelompok yang bersifat heterogen dari segi kemampuan maupun jenis kelamin. Terbentuk delapan kelompok masing-masing kelompok beranggotakan 6 orang siswa. Pemberian namadiurutkan dari kelompok 1 higga kelompok 8 .

f. Peneliti membuat nomor absen siswa untuk dipasang didada siswa, tujuannya yaitu untuk mempermudah melihat aktivitas siswa.

\section{Pelaksanaan}

Proses pembelajaran pada siklus I dilaksanakan dalam 2 kali pertemuan, yaitu pada tanggal 27 Oktober dan 03 Nopember 2014. Kompetensi dasar yang ingin dicapai pada siklus I yaitu Mendeskripsikan sistem Pemilu dan
Pilkada di Indonesia. Proses pembelajaran digambarkan sebagai berikut.

\section{Pertemuan I}

Pertemuan pertama pada siklus satu berlangsung selama 2 jam pelajaran yaitu 2 × 35 menit di kelas VI-A SD Negeri 088 Panyabungan. Peneliti masuk kekelas VI di jam pelajaran dan 2 tepatnya pukul 08.00 WIB - 09.10 WIB untuk melaksanakan KBM. Saya masuk kekelas dengan mengucapakan salam dan langsung menuju tempat duduk guru yang berada didepan kelas. suasana kelas tenang dengan kondisi siswa bersiap membuka buku pelajaran PKN.

Kemudian saya berdiri didepan kelas menghadap anak didik dan memperhatikan keadaan kelas mulai dari lantai hingga kerapian pakaian siswa.

Kemudian saya membuka pelajaran dengan menanyakan kabar seluruh kelas dengan melanjut mengecek daftar hadir siswa.

Guru: "apa kabar anak-anak hari ini?"

Siswa: "baik pak! (menjawab dengan serentak)".

Tidak berlangsung lama, saya tidak mendapati siswa yang tidak hadir didalam kelas. Keadaan kelas lengkap dan tidak ada siswa yang berada diluar kelas.

Saya melanjutkan kepada kelas, saya samapaikan materi yang akan dibahas dan menginformasikan tujuan 
pembelajaran yang akan mereka capai.

Materi hari ini yang akan dibahas adalah Sistem pemerintahan Republik Indonesia. Sub materi Pemilihan umum dan pemilihan kepala daerah.

Pembelajaran dimulai dengan pendahuluan yang bertujuan untuk memberikan motivasi awal dan arah pembelajaran kepada siswa. Pada tahap ini guru memotivasi siswa

dengan memberikan pertanyaan "Pada awal kemerdekaan, siapa Presiden Repbulik Indonesia Pertama sekali?

Dari pertanyaan ini guru mengarahkan siswa kepada sub materi tentang Pemilu. Ahmad Sarkawi menjawab pertanyaan peneliti, "Iya pak, saya pernah baca dibuku awal kemerdekaan presiden Indonesia saat itu Sukarno!." Selanjutnya guru mengemukakan pentingnya materi tersebut dalam disiplin ilmu PKn dan kehidupan sehari-hari. Pada tahap pendahuluan ini siswa tampak antusias hal ini terlihat dari semangatnya siswa untuk mendengarkan dan menjawab pertanyaan yang diberikan guru. Selanjutnya siswa dibimbing menuju ke inti pembelajaran.

\section{1) Tahap Penomoran (Numbering)}

Kegiatan penomoran diawali dengan pembagian siswa dalam kelompok- kelompok secara heterogen, kemudian siswa diminta duduk dalam kelompoknya masingmasing. Pada saat pembagian kelompok terjadi sedikit kegaduhan, ada lebih dari 10 siswa yang mengeluh karena tidak satu kelompok dengan teman karibnya. Setelah diberi penjelasan bahwa semua teman sama saja dan dengan kelompok yang seperti ini akan lebih mudah untuk saling membantu, siswa mulai tenang kembali.

Dalam satu kelompok terdiri atas 6 orang siswa. Selanjutnya guru memberikan nomor 1-6 kepada masing-masing siswa. Selain nomor tersebut siswa juga diberi nomor absen yang dipasang di punggung untuk mempermudah observer untuk mengobservasi aktivitas siswa.

\section{Tahap Pengajuan Pertanyaan (Questioning)}

Pertanyaan yang diberikan peneliti kepada siswa pada tahap ini tidak dilakukan secara lisan, tapi dengan memberikan lembar kerja siswa (LKS I) kepada setiap siswa. Pada tahap ini terdapat dua orang siswa yang menanyakan tentang cara mengerjakan, dan tempat mengerjakan. Seorang siswa lain menanyakan tentang cara pengerjaannya secara individu atau kelompok. Setelah diberi tahu oleh guru cara mengerjakan LKS, siswa mulai mengerti, tapi kemudian ada siswa yang menanyakan beberapa pertanyaan dalam LKS yang belum dimengerti.

\section{Tahap Berpikir Bersama (Heads} Together)

Sebelum siswa melakukan diskusi guru memberi tahu batasan waktu untuk melakukan diskusi kelompok adalah 20 menit. Pada tahap berpikir bersama siswa diarahkan untuk menjawab pertanyaan yang ada dalam LKS dengan membaca pustaka. Tapi pustaka yang dimiliki siswa sangat terbatas yaitu berupa LKS dan hanya dua orang siswa yang memiliki buku pegangan, jadi guru memberikan 
pinjaman buku kepada kelompok yang tidak memiliki buku pegangan. Dalam memberikan jawaban yang ada dalam LKS siswa dihimbau untuk berdiskusi dengan teman dalam kelompok. Guru memberitahu kepada siswa bahwa dalam menjawab pertanyaan dalam LKS semua anggota kelompok harus benar-benar mengerti jawabannya karena nanti yang menjawab dipilih secara acak. Pada tahap ini siswa sudah tampak antusias mengikuti diskusi dengan memberi masukan atas pertanyaan dan siswa lain mencatatnya. Akan tetapi masih banyak siswa yang masih pasif dalam diskusi kelompok.

\section{Tahap Menjawab Pertanyaan (Answering)}

Semua siswa diberitahu agar menyiapkan jawaban atas pertanyaan yang ada dalam LKS I. Tahap pemberian jawaban dimulai dengan membahas LKS I. Guru menyebut nomor 3, tampak semua siswa dari masing-masing kelompok yang bernomor 3 mengangkat tangan kemudian guru menunjuk siswa yang bernomor 3 dari kelompok 1 untuk menjawab pertanyaan nomor 1 , sedangkan kelompok lain memberikan balikan dan menambahkan jika ada yang kurang. Siswa yang bernomor sama dari kelompok lain berebut untuk memberikan balikan dan menambahkan jawaban, sampai sampai ada siswa yang mengangkat tangan sambil berdiri agar ditunjuk.

Pada tahap pemberian jawaban siswa tampak antusias menjawab pertanyaan meski ada beberapa yang masih pasif, ada juga yang bermain main dengan temannya bahkan ada yang mengganggu teman lain yang serius memperhatikan. Melihat hal tersebut peneliti menghimbau siswa untuk memperhatikan dan lebih aktif.

Pada tahap ini jawaban yang diberikan
siswa dari masing-masing kelompok
cenderung sama, dan memakan waktu
lama karena siswa gaduh berebut
untuk menjawab pertanyaan pertama.
Pelaksanaan pemberian jawaban ini
secara umum berlangsung tertib, tapi
memakan waktu lebih banyak dari
yang ditentukan. Setelah dilakukan
penarikan kesimpulan siswa tidak
sempat melakukan penilaian diri.
Sebelum pembelajaran berakhir guru
minta siswa untuk mempelajari materi
yang telah dipelajari.

\section{Tahap Observasi}
a. Data Observasi Aktivitas Siswa

Penilaian aktivitas diperoleh dari lembar observasi aktivitas dilakukan pada saat siswa bekerja dalam kelompok diskusi. Pengamatan dilakukan oleh dua pengamat selama 20 menit kerja kelompok dalam setiap kegiatan belajar mengajar (KBM).

\section{Tabel 4.1 Skor Aktivitas Belajar Siswa Siklus I}

\begin{tabular}{|c|c|c|c|}
\hline No & Aktivitas & Skor & Proporsi \\
\hline 1 & Menulis/membaca & 89 & $37 \%$ \\
\hline 2 & $\begin{array}{l}\text { Mengerjakan } \\
\text { LKS }\end{array}$ & 46 & $19 \%$ \\
\hline 3 & $\begin{array}{l}\text { Bertanya pada } \\
\text { teman }\end{array}$ & 35 & $15 \%$ \\
\hline 4 & $\begin{array}{l}\text { Bertanya pada } \\
\text { guru }\end{array}$ & 44 & $18 \%$ \\
\hline 5 & $\begin{array}{l}\text { Yang tidak } \\
\text { relevan dengan } \\
\text { KBM }\end{array}$ & 26 & $11 \%$ \\
\hline & JUMLAH & 240 & $100 \%$ \\
\hline
\end{tabular}


Dengan pengamatan setiap dua menit, maka nilai maksimum yang mungkin teramati untuk satu kategori aktivitas selama 20 menit tersebut adalah 10 kali. Nilai aktivitas untuk setiap KBM adalah rata-rata dari nilai aktivitas kedua pengamat.Karena dalam satu siklus terdapat dua KBM.

Data aktivitas belajar siswa ditampilkan dalam bentuk diagram dapat dilihat pada gambar 4.1 berikut ini.

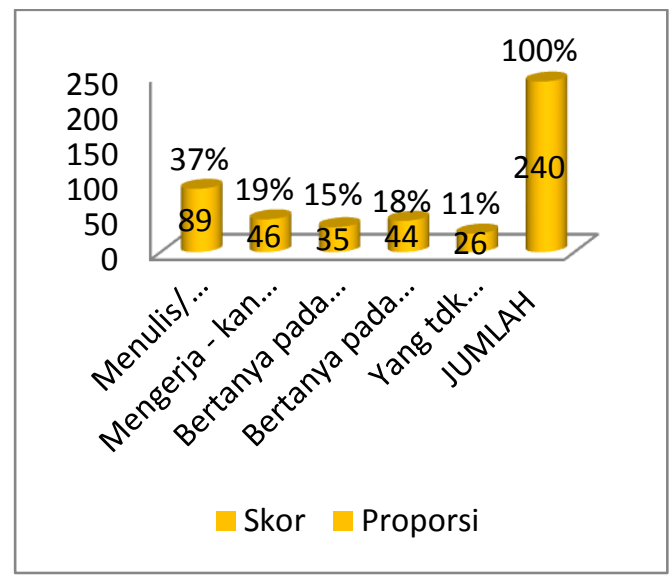

\section{Gambar 4.1 Diagram Aktivitas Belajar Siswa Siklus I}

b. Data Hasil Belajar Siswa Nilai hasil Formatif dalam

Siklus I disajikan dalam Tabel 4.2.

Tabel 4.2 Deskripsi Data Formatif I

\begin{tabular}{|c|c|c|c|c|}
\hline Nilai & Frekuensi & $\begin{array}{l}\text { Rata- } \\
\text { Rata }\end{array}$ & $\begin{array}{c}\text { S. } \\
\text { Deviasi }\end{array}$ & $\begin{array}{c}\mathrm{K} \\
\text { Klasikal }\end{array}$ \\
\hline 40 & 9 & \multirow{5}{*}{71} & \multirow{5}{*}{20,52} & \multirow{5}{*}{$54,34 \%$} \\
\hline 60 & 12 & & & \\
\hline 80 & 16 & & & \\
\hline 100 & 9 & & & \\
\hline Jumlah & 46 & & & \\
\hline
\end{tabular}

Merujuk pada Tabel 4.2 tersebut, nilai terendah formatif I adalah 40 berjumlah 9 orang siswa dan tertinggi100 dengan 9 orang siswa. 21 orang siswa dengan nilai dibawah kriteria ketuntasan minimal dan ketuntasan klasikal adalah sebesar 54,34\%. Nilai ini berada di bawah kriteria keberhasilan sehingga dapat dikatakan KBM siklus I kurang berhasil memberi ketuntasan belajar. Data hasil formatif I ini dapat disajikan kembali dalam grafik histogram sebagai berikut:

\section{Gambar .4.2 Grafik Data Hasil}

\section{Formatif I}

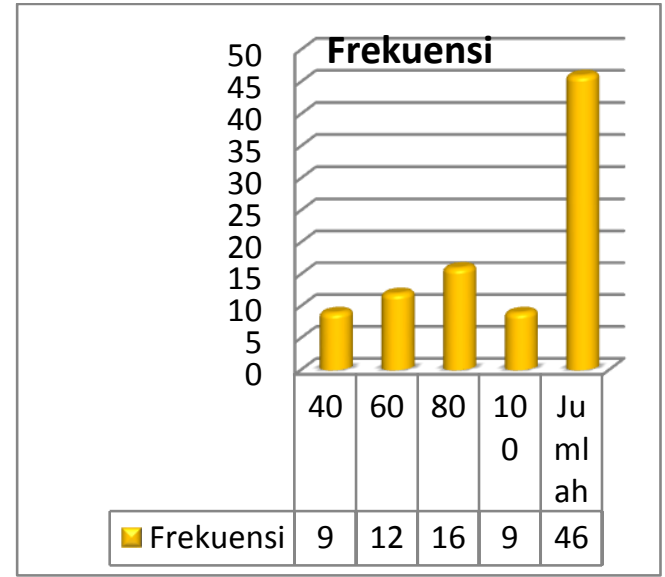

\section{Tahap Refleksi I}

Merujuk pada Tabel 4.1. aktivitas menulis dan membaca paling dominan dengan 37\%, namun aktivitas mengerjakan LKS masih cukup besar 19\%, disusul bertanya kepada teman $15 \%$, kemudian bertanya pada guru $18 \%$. Muncul pula aktivitas tidak relevan dengan KBM sebesar $11 \%$.

Sementara data hasil belajar siswa merujuk pada Tabel 4.2 
menunjukkan nilai terendah sebesar 40 untuk 9 siswa, tertinggi 100untuk 9 siswa. Dengan KKM sebesar 70 untuk PKn maka siswa dikatakan tuntas sebanyak 25dari 46 siswa atau ketuntasan klasikal sebesar 54,34\% sehingga belum mencapai kriteria yang diharapkan sebesar $85 \%$.

Berdasarkan hasil observasi pada penerapan model pembelajaran Numbered Heads Together (NHT) siklus I di kelas VI-A SD Negeri 088 Panyabungan, Kecamatan Panyabungan Kabupaten Mandailing Nataldapat diperoleh hasil refleksi sebagai berikut:

a. Masih terjadi kesalahankesalahan dalam penarikan kesimpulan oleh siswa yang menandakan terjadi kesalahpahaman dalam diskusi kelompok.

b. Jawaban siswa yang sama dengan jawaban temannya masih banyak hal ini menunjukkan bahwa siswa cenderung untuk menyalin jawaban temannya.

c. Sebagian siswa masih belum terbiasa dengan alur pembelajaran atau masih binggung diperlihatkan dengan besarnya aktivitas menulis dan membaca yang baru dilakukan disekolah (37\%) yang seharusnya sudah dilakukan dirumah.

d. Sebagian siswa belum memiliki rasa tanggung jawab terhadap tugasnya dalam

diperlihatkan dengan aktivitas kerja yang hanya mencapai $19 \%$.

e. Ada siswa yang lebih suka mengerjakan soal sendiri

f. Pada tahap pengajuan pertanyaan sebagian besar siswa tidak memusatkan perhatian dalam mengerjakan LKS, terbukti masih banyak persentase aktivitas yang tidak relevan dengan KBM yaitu $11 \%$.

g. Pada pertemuan ke II aktivitas siswa sudah mulai meningkat, siswa sudah mulai memperhatikan dan mengerjakan LKS dengan lebih serius.

h. Waktu yang digunakan dalam kegiatan pembelajaran tidak sesuai dengan waktu yang direncanakan sebelumnya.

\section{Tindakan pembelajaran}

Perbaikan

Hasil refleksi tersebut dijadikan bahan pertimbangan untuk perbaikan-perbaikan yang akan dilaksanakan pada siklus II. Tindakan-tindakan yang perlu dilakukan untuk meningkatkan aktivitas dan hasil belajar pada siklus II adalah sebagai berikut:

a. Penjelasan dan Penekanan kepada siswa tentang pembelajaran kooperatif diantaranya kerjasama dalam menyelesaikan tugas, saling membantu dan 
berdiskusi harus diperhatikan.

b. Pada pelaksanaan siklus II penomoran siswa pada masing-masing kelompok sama dengan pelaksanaan siklus I untuk menghindari siswa saling berebut dalam penentuan nomor.

c. Guru harus lebih sering mengunjungi kelompok pada tahap berpikir bersama berlangsung untuk menghindari siswa ngobrol sendiri di luar materi pelajaran.

d. Guru harus memberikan penghargaan bagi siswa/kelompok yang mendapatkan skor tertinggi dan menyajikan jawaban terbaik.

e. Pengelolaan waktu diharapkan lebih efisien.

f. Guru memberikan informasi kepada siswa bahwa pertanyaan-pertanyaan dalam LKS akan ditanyakan kembali pada saat tes agar siswa lebih memperhatikan jawaban yang dikemukakan temannya kepada seluruh kelas.

\section{Siklus II}

Siklus II dilaksanakan dalam dua kali pertemuan. Dalam dua kali pertemuan untuk pembelajaran, siswa diberikan Lembar Kerja Siswa (LKS). Pada akhir siklus siswa mengerjakan soal tes. Tindakan yang dilaksanakan pada Siklus II adalah sebagai berikut:

\section{Tahap Perencanaan}

Siklus kedua ini semua kegiatan tetap sama seperti pada Siklus I, hanya saja materi yang disampaikan berbedadan dilakukan perbaikan kelemahan pada Siklus I. Perbaikan yang akan dilakukan pada Siklus II adalah sebagai berikut:

a. Untuk membantu siswa menyesuaikan diri dalam alur pembelajaran diskusi dan memfokuskan siswa maka tindakan Siklus II adalah dengan memberikan tugas mengerjakan contoh soal untuk materi berikutnya dan menampilkan media untuk membantu siswa memunculkan ide-ide dalam diskusi.

b. Untuk memunculkan rasa tanggung jawab masingmasing siswa maka tiap kelompok dibantu dalam membagi spesifikasi siswa dalam tugas masing-masing dan memberi peringatan bahwa tiap siswa akan ditagih pekerjaannya dalam kegiatan bertanya.

c. Untuk menyiasati masalah ini kesulitan siswa menarik kesimpulan dan mengatasi kesalahpahaman, guru akan memberikan pertanyaan pancingan kepada siswa dengan menunjuk beberapa siswa untuk menjawab. 
Keseluruhan dari pernyataan siswa tersebut kemudian disaring dan diberi penjelasan oleh guru jika masih ada yang belum paham. Selanjutnya akanditarik kesimpulan bersama sehingga siswa bisa lebih mengerti apa yang telah mereka kerjakan dalam kelompok masing-masing.

Kegiatan diawali dengan perencanaan meliputi menyiapkan Rencana Pelaksanaan Pembelajaran (RPP 3 dan 4), LKS 3 dan 4, lembar observasi aktivitas, angket respon siswa dan soal tes Formatif II. Seperangkat instrumeninstrumen tersebut disusun dalam diskusi peneliti bersama pembimbing dan pendamping penelitian beserta guru sejawat sebelum pelaksanaan pembelajaran berlangsung.Adapun sub materi yang akan dibahas pada siklus II ini yaitu secara berturut pertemuan 3 dan pertemuan 4 adalah "Mendeskripsikan lembagalembaga Negara". Pertemuan ke 4 yaitu "Mendeskripsikan beberapa fungsi dan tugas pemerintah".

\section{Tahap \\ Pembelajaran}

Pelaksanaan

Pembelajaran Siklus II dilaksanakan sama dengan Siklus I dengan mempertimbangkan tindakan perbaikan yang direncanakan dalam dua kali pertemuan (KBM). KBM pertama dilaksanakan dalam 2 × 35 menit sementara KBM kedua terpotong dengan kegiatan Formatif II. Tiap KBM dilaksanakan sesuai RPP dengan menerapkan model pembelajaran kooperatif type Numbered Heads Together (NHT). Dalam pelaksanaan pembelajaran dilakukan pemungutan data observasi aktivitas belajar dan dokumentasi penelitian. Adapun proses pembelajaran pada setiap pertemuan adalah:

Pertemuan III (10 November 2014)

Pertemuan pembelajaran III siklus kedua, diawali dengan mempresensi kehadiran siswa, kemudian siswa disuruh untuk duduk dikelompoknya masingmasing seperti siklus I. sebelum masuk kepada materi, guru membagikan hasil tes pada siklus I, pada saat pembagian hasil tes siswa saling menanyakan hasilnya kepada teman. Guru meminta siswa agar tenang.

Pertemuan ini kegiatan pembelajaran yaitu mendeskripsikan lembagalembaga negara.

Kegiatan berikutnya adalah siswa belajar dalam kelompok dengan menggunakan metode Numbered Hrads Together . Guru membimbing siswa untuk memulai pelajaran secara kelompok.

1) Tahap (Numbering)

Pada tahap penomoran ini, nomor siswa sama dengan pertemuan sebelumnya pada siklus I. Penomoran yang sama ini bertujuan untuk menghindari siswa saling berebut nomor 
tertentu yang diinginkan.

\section{2) Tahap Pengajuan Pertanyaan (Questioning)}

Pengajuan pertanyan pada tahap ini dalam bentuk Lembar Kerja siswa (LKS III). Setelah LKS dibagikan siswa diminta untuk membaca perintah dan pertanyaan yang ada dalam LKS, guru juga memberi kesempatan kepada siswa untuk bertanya jika ada masalah. Selanjutnya guru menginformasikan waktu yang digunakan untuk diskusi kelompok. Setelah mengerti cara mengerjakan siswa diarahkan untuk menjawab pertanyaan yang ada dalam LKS dengan membaca buku atau literatur lain yang dimiliki oleh siswa.

\section{3) Tahap Berpikir Bersama (Heads Together)}

Guru membimbing siswa untuk berdiskusi dengan kelompoknya untuk menemukan jawaban yang ada dalam LKS. Guru mengingatkan siswa agar semua anggota kelompok benarbenar paham dan mengerti jawaban dari masing-masing pertanyaan, apabila belum mengerti disarankan untuk bertanya pada anggota kelompok lain yang mengerti. Selain itu guru juga memotivasi siswa untuk tidak takut mengeluarkan pendapat karena semua aktivitas siswa akan direkam. Tahap berpikir bersama pada siklus II terlihat lebih antusias dibanding siklus I, siswa sudah mulai berani mengangkat tangan dan mengeluarkan pendapat.

\section{4) Tahap}

Memberikan Jawaban (Answering)
Guru memberikan informasi bahwa waktu untuk berpikir bersama telah selesai. Semua siswa diberi tahu agar menyiapkan hasil diskusi kelompok berupa jawaban LKS yang telah disepakati.

Tahap berpikir bersama diawali dengan membahas LKS II. Pada tahap ini yang menjawab soal nomor 1 adalah siswa yang bernomor 6, siswa yang bernomor 6 angkat tangan semua dan yang menjawab siswa dari kelompok 5 . Selanjutnya soal nomor 2 dijawab oleh siswa yang bernomor 5 dan yang menjawab adalah siswa dari kelompok 3. Karena waktu telah berakhir maka guru mengatakan pada pertemuan mendatang akan membahas tentang beberapa fungsi dan tugas pemerintah, siswa diminta untuk membaca kembali pelajaran dirumah dan mempersiapkan diri untuk materi pelajaran pertemuan berikutnya.. Lalu guru memberi salam dan meninggalkan ruangan.

Pertemuan IV (17 November 2014)

Pertemuan ke empat ini
siswa sudah langsung duduk di
kelompoknya sendiri $r$ tanpa
diperintah. Setelah melihat
kehadiran siswa guru memotivasi
siswa dengan bertanya," apakah
kalian sudah mempersiapkan diri
untuk belajar dari rumah?" Siswa
serempak menjawab "sudah pak".
Guru melanjutkan pertanyaan.
eliti : "Devi, sebuatkan fungsi
BPK?"
ha : BPK itu berfungsi untuk
mengaudit keuangan Negara Pak!
eliti : Ya benar, ada lagi pendapat
yang lain?
ila : BPK Itu Badan Penyidik




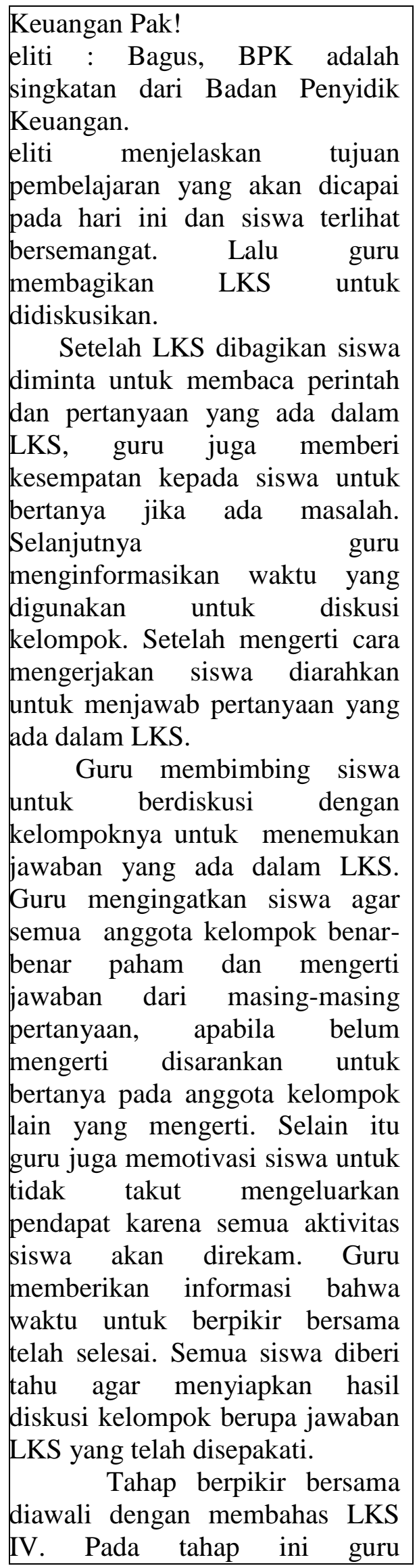

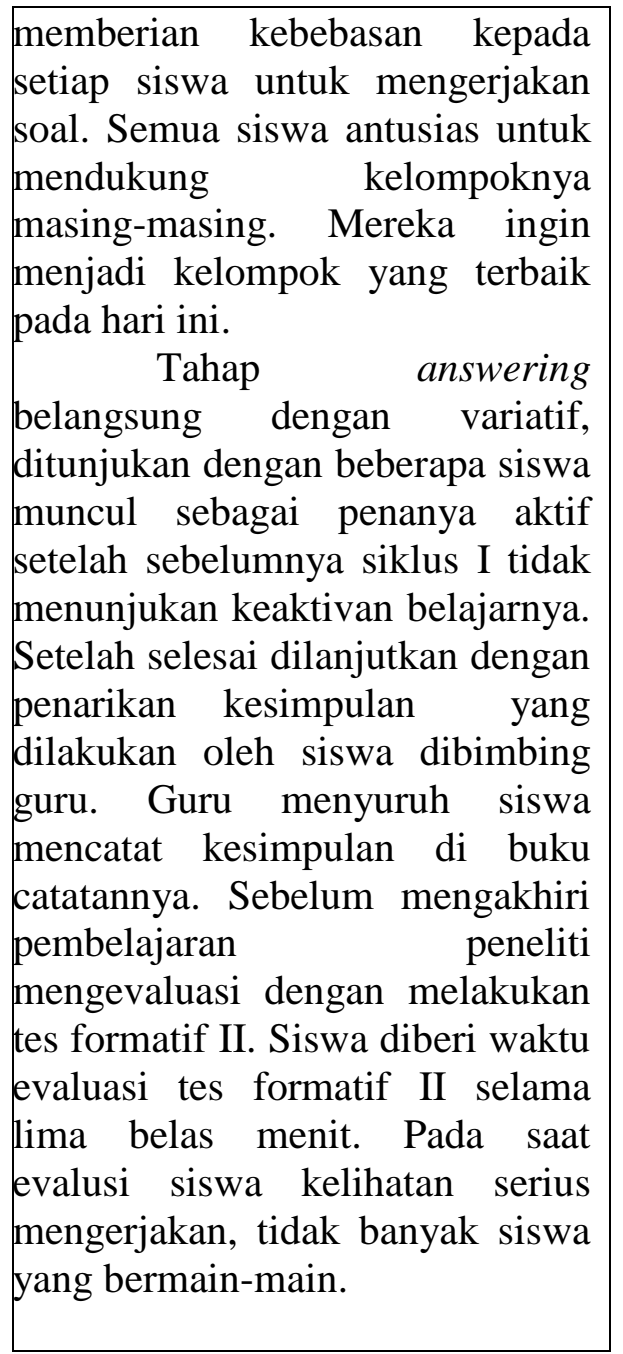

\section{Tahap Observasi}

a. Data Hasil Observasi

Data hasil observasi Siklus

II ditunjukkan dalam Tabel 4.3.merujuk pada tabel tersebut. Kegiatan menulis /membaca adalah $27 \%$, peningkatan terjadi pada kegiatan mengerjakan LKSmenjadi $32 \%$, kemudian bertanya pada teman $23 \%$, dan bertanya pada guru $15 \%$. Kegiatan tidak relevan dengan KBM masih muncul dengan proporsi $4 \%$. 
Tabel 4.3 Data Aktivitas Belajar

Siswa Siklus II

\begin{tabular}{|c|c|c|c|c|c|c|c|c|c|}
\hline \multirow{2}{*}{ No } & \multirow{2}{*}{ Aktivitas } & \multicolumn{3}{|c|}{ Siklus II } & \multicolumn{2}{|c|}{ Tabel 4.4} & & & \\
\hline & & Jumlah & Skor & Persentasi & \multirow{2}{*}{\multicolumn{5}{|c|}{$\begin{array}{l}\text { Tabel 4.4 Deskripsi Data Hasil } \\
\text { Formatif II }\end{array}$}} \\
\hline 1 & Menulis/membaca & 60 & 15 & $27 \%$ & & & & & \\
\hline \multirow{2}{*}{2} & Mengerjakan & 70 & 175 & $32 \%$ & \multirow[b]{2}{*}{ Nilai } & \multirow[b]{2}{*}{ Frekuensi } & \multirow[b]{2}{*}{$\begin{array}{l}\text { Rata- } \\
\text { Rata }\end{array}$} & \multirow[b]{2}{*}{$\begin{array}{c}\text { S. } \\
\text { Deviasi }\end{array}$} & \multirow[b]{2}{*}{$\begin{array}{c}\mathrm{K} \\
\text { Klasikal }\end{array}$} \\
\hline & $\begin{array}{l}\text { LKS } \\
\text { Bertanva Kenada }\end{array}$ & & & & & & & & \\
\hline 3 & teman & 50 & 12,5 & $23 \%$ & 60 & 4 & \multirow{6}{*}{86} & \multirow{6}{*}{12,76} & \multirow{6}{*}{$91,30 \%$} \\
\hline \multirow{2}{*}{4} & Bertanya kepada & 32 & 8 & $15 \%$ & 70 & 7 & & & \\
\hline & guru & & & & 80 & 6 & & & \\
\hline \multirow{2}{*}{5} & Yang tidak & \multirow[b]{2}{*}{8} & \multirow[b]{2}{*}{2} & \multirow{2}{*}{$4 \%$} & 90 & 17 & & & \\
\hline & $\begin{array}{l}\text { relevan dengan } \\
\text { KBM }\end{array}$ & & & & 100 & 12 & & & \\
\hline & JUMLAH & 220 & 55 & $100 \%$ & Jumlah & 46 & & & \\
\hline
\end{tabular}

klasikal sebesar 91,30\%. Data hasil belajar Siklus II disajikan dalam Tabel 4.4

Data Hasil Formatif II ini dapat disajikan kembali dalam bentuk grafik histogram dan dapat dilihat pada Gambar 4.4.

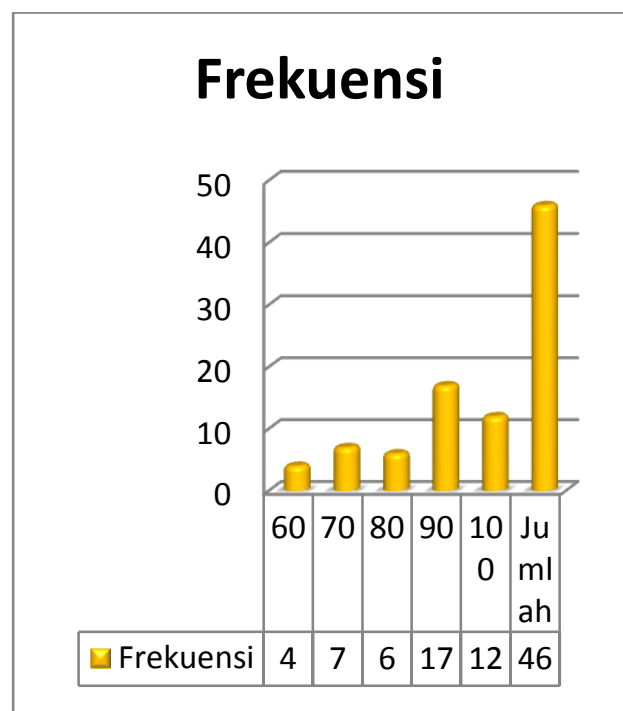

\section{Gambar 4.4 Grafik Hasil Formatif Siklus II}

Merujuk pada Tabel 4.4 dapat dilihat nilai rata-rata tes siswa sebelum diterapakan model pembelajaran kooperatif tipe Numbered Head Together adalah 
50 dan setelah diterapkan model pembelajaran kooperatif tipe Numbered Head Together meningkat menjadi 71 pada Siklus I dan 86 pada Siklus II. Ketuntasan belajar secara klasikal juga mengalami peningkatan, sebelumnya hanya 6 orang siswa yang memperoleh nilai $70 \mathrm{ke}$ atas sebelum dilakukan pembelajaran atau ketuntasan belajar secara klasikal 13,95\%, menjadi 25 siswa dari 46 siswa dalam kelas, dengan kata lain ketuntasan belajar secara klasikal sebesar $54,34 \%$ pada Siklus I dengan tolak ukur ketuntasan klasikal sebesar 85\% maka disimpulkan KBM Siklus I belum memberikan ketuntasan klasikal pada siswa.

Merujuk Tabel 4.4 pada Siklus II 42 siswa dari 46 siswa dalam kelas memperoleh nilai diatas ketuntasan individual atau dengan kata lain ketuntasan belajar secara klasikal 91,30\% dengan tolak ukur ketuntasan klasikal sebesar $85 \%$ maka KBM Siklus II dapat dikatakan cukup berhasil memberikan ketuntasan belajar secara klasikal meskipun masih ada4 orang siswa yang hasil belajarnya belum tuntas. Perhitungan ketuntasan belajar klasikal Siklus II:
Tabel 4.5.Rekapitulasi Uji awal, Formatif I, dan Formatif II

\begin{tabular}{|c|c|c|c|}
\hline Hasil Tes & Pretes & $\begin{array}{c}\text { Format } \\
\text { if I }\end{array}$ & $\begin{array}{c}\text { Formatif } \\
\text { II }\end{array}$ \\
\hline $\begin{array}{c}\text { Nilai } \\
\text { Tertinggi }\end{array}$ & 75 & 100 & 100 \\
\hline $\begin{array}{c}\text { Nilai } \\
\text { terendah }\end{array}$ & 30 & 40 & 60 \\
\hline $\begin{array}{c}\text { Rata-rata } \\
\text { nilai tes }\end{array}$ & 50 & 71 & 86 \\
\hline $\begin{array}{c}\text { Ketuntasan } \\
\text { klasikal }\end{array}$ & 13,95 & $54,34 \%$ & $91,30 \%$ \\
\hline
\end{tabular}

Untuk menggambarkan secara lebih jelas, data pada Tabel 4.5 dapat disajikan kembali dalam bentuk diagram batang atau histogram seperti Grafik 4.5

$$
\begin{aligned}
& \begin{array}{c}
\text { Ketuntasabelajarkelas }=\frac{42}{46} \times 100 \% \\
\text { Peningkatan hasil tes siswa }
\end{array} \\
& \text { dapat dilihat melaui Tabel dan } \\
& \text { histogram berikut: }
\end{aligned}
$$

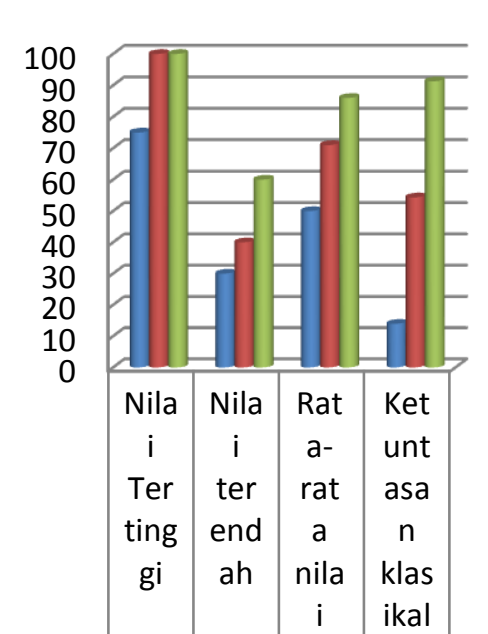




\section{Gambar 4.5 Grafik Hasil Belajar}

\section{Kognitif}

\section{a. Tahap Refleksi II}

Sampai akhir Siklus II telah terlihat perubahan aktivitas siswa yang lebih baik dibandingkan Siklus I. Aktivitas menulis dan membaca menurun dari $37 \%$ menjadi $27 \%$. Aktivitas mengerjakan LKS dari siklus I dan II memiliki proporsi yang berbeda yaitu $19 \%$ meningkat pada siklus II $32 \%$.

Sementara aktivitas bertanya pada teman mengalami perubahan dari $15 \%$ menjadi $23 \%$. Bertanya pada guru mengalami penurunan sedikit dari $18 \%$ menjadi 15\%. Dan aktivitas tidak relevan mengalami penurunan dari $11 \%$ menjadi $4 \%$.

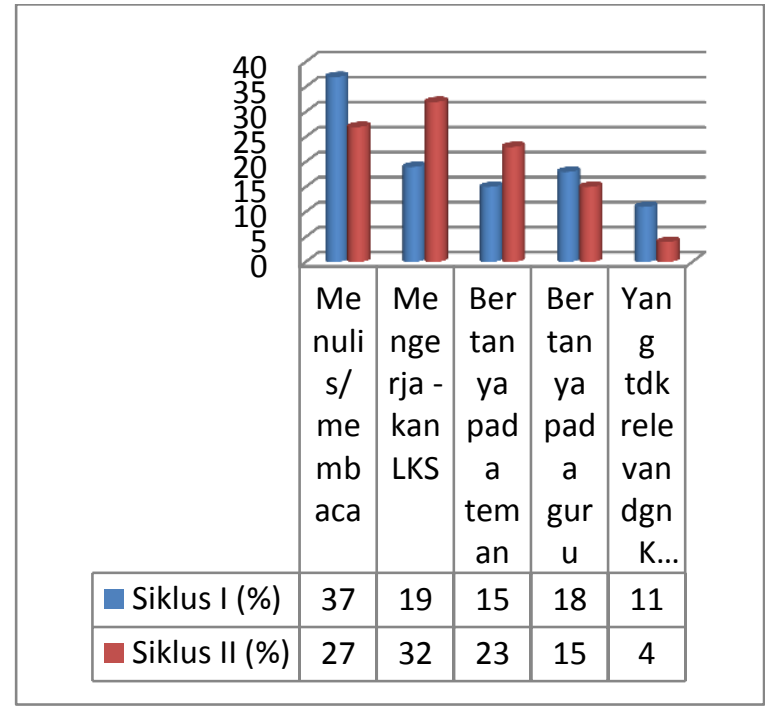

\section{Gambar 4.6 Grafik perubahan aktivitas belajar}

Berdasarkan hasil observasi aktivitas, tes hasil belajar siswa terhadap mata pelajaran PKn pada siklus II hasil refleksi penerapan model pembelajaran Numbered Heads Together adalah sebagai berikut:

1. Pembelajaran yang dilakukan sudah sesuai dengan RPP

2. Pembelajaran sudah mencerminkan model Numbered Heads Together

3. Guru telah memotivasi siswa sehingga siswa mulai berani mengeluarkan pendapat.

4. Guru telah memberikan penghargaan bagi kelompok yang mempunyai skor tertinggi.

5. Aktivitas dan Hasil belajar siswa mengalami peningkatan dibanding siklus I sehingga memenuhi ketuntasan belajar klasikal. 
Dari hasil refleksi tersebut telah menunjukkan ketercapaian indikator keberhasilan, sehingga pelaksanaan tindakan siklus II dikatakan berhasil.

\section{SIMPULAN DAN SARAN}

\section{Simpulan}

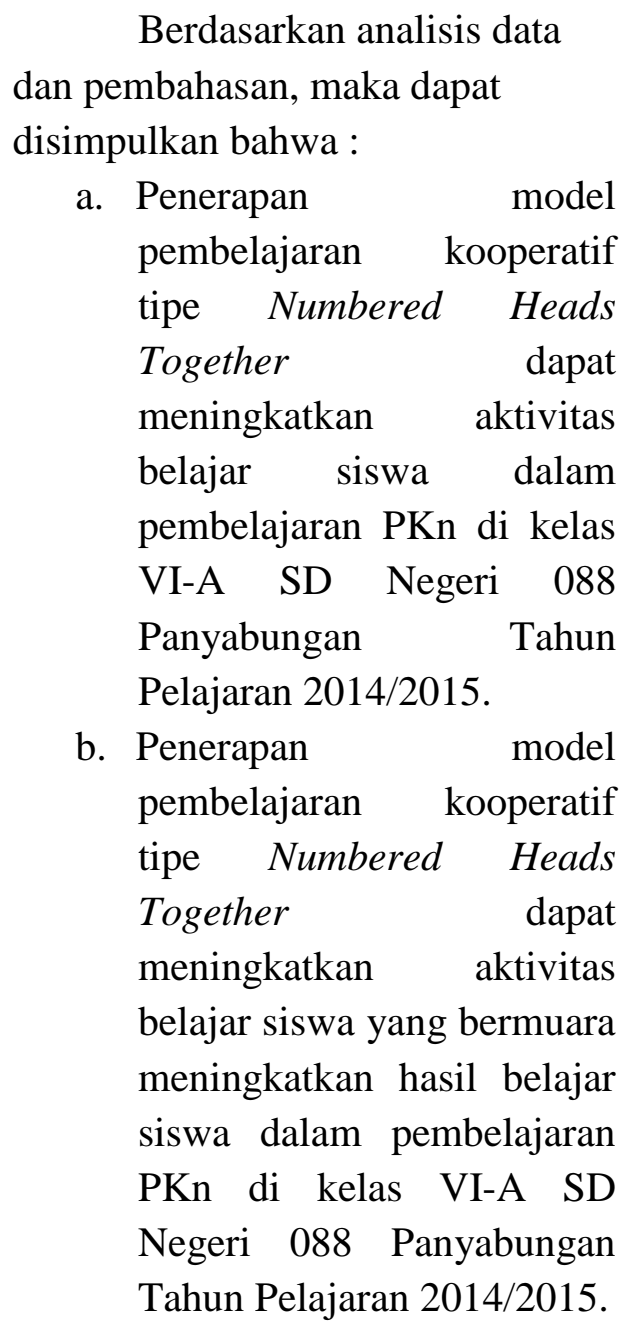

\section{Saran}

Dari hasil dan pembahasan penelitian maka disarankan :

a. Pelaksanakan pembelajaran kooperatif model Numbered Heads Together hendaknya dapat digunakan dalam pembelajaran di kelas khususnya saat pembelajaran PKn.

b. Guru dapat menyesuaikan topik yang dianggap tepat dengan pembelajaran kooperatif model Numbered Heads Together dalam proses belajar mengajar sehingga diperoleh hasil yang optimal.

c. Sebagai rujukan dan perbandingan bagi sekolah baik guru maupun pimpinan sekolah untuk mengunakan pilihan model pembelajaran yang inovatif.

d. Untuk penelitian yang serupa hendaknya dilakukan perbaikan - perbaikan agar diperoleh hasil yang lebih baik.

\section{DAFTAR RUJUKAN}

Arifin, Z. 2009. Evaluasi Pembelajaran. Bandung: PT Remaja Rosdakarya.

Arikunto, S. (2002). Dasar-Dasar Evaluasi Pendidikan. Jakarta: Bumi Aksara.

Aqib, Z. (2006). Peneltian Tindakan Kelas. Bandung: Penerbit Yrama Widya. Aunurrahman .(2009). Belajar dan Pembelajaran. Bandung: Alfabeta

Dimyat, dkk. 2009. Belajar dan Pembelajaran. Jakarta: Rineka Cipta.

Drs. Hamdani, M.A. 2010. Strategi Belajar Mengajar. Bandung: Pustaka Setia. 
Dimyati, dan Mudjiono. (2006).

Belajar dan Pembelajaran.

Jakarta: PT Rineka Cipta.

Djamarah, Syaiful Bahri dan

Aswan Zain. 2006. Startegi

Belajar Mengajar. Jakarta:

PT Rineka Cipta.

Istarani. 2011. Model Pembelajaran

Inovatif (Referensi Guru

Dalam Menentukan Model

Pembelajaran). Medan:

Media Persada.

Sardiman, A. M. (2006). Interaksi

dan Motivasi Belajar

Mengajar. Jakarta: Raja

Grafindo Persada.

Sukmadinata, Nana Syaodih. 2005.

Metode Penelitian Pendidikan.

Bandung: PT. Remaja Rosdakary. 